\title{
Spatial, seasonal and ontogenetic variation in the diet of Astyanax aff. fasciatus (Ostariophysi: Characidae) in an Atlantic Forest river, Southern Brazil
}

\author{
Luciano Lazzarini Wolff ${ }^{1}$, Vinícius Abilhoa ${ }^{2}$, Flavia Sant’Anna Rios ${ }^{1}$ and Lucélia Donatti ${ }^{1}$
}

This study described the feeding habits of the characin Astyanax aff. fasciatus. The diet compositions of specimens from two sites (A and B) on a river in Southern Brazil were compared according to the size of individuals and seasonal period. The collections were performed monthly from March 2005 to February 2006, where the stomach contents of 290 specimens were assessed. Food items for A. aff. fasciatus were basically composed of plants and insects, especially leaf fragments, seeds, fruits, filamentous algae, aquatic and terrestrial insects and insect fragments. At site A, the most common items were insect and plant fragments. Conversely at site B, plant fragments were more representative. In general, all items of animal origin showed the highest feeding index values at site A, whereas at site B detritus and grass items were more abundant. The composition of items varied seasonally, with higher diversity of items being recorded during the spring at both sites. Smaller individuals preferred items of animal origin, while the larger ones consumed mainly items of plant origin. According to its size, $A$. aff. fasciatus in this study may be considered a species with insectivorous tendencies when immature or herbivorous tendencies when adult. Nevertheless, its feeding habits may be flexible according to resource availability, showing wide ontogenetic, besides spatial and temporal variation.

Este estudo descreveu os hábitos alimentares do lambari Astyanax aff. fasciatus. Foram comparadas as composições alimentares de espécimes de dois sítios (A e B) de um rio no sul do Brasil de acordo com o tamanho dos indivíduos e do período sazonal. As coletas foram realizadas mensalmente de março de 2005 a fevereiro de 2006, sendo o conteúdo estomacal de 290 exemplares analisado. A dieta de A. aff. fasciatus foi composta basicamente por plantas e insetos, especialmente fragmentos de folhas, sementes, frutos, algas filamentosas, insetos aquáticos e terrestres e fragmentos de insetos. No sítio A, os itens de maior importância foram fragmentos de insetos e plantas. Ao contrário no sítio B, fragmentos de plantas foram mais representativos. Em geral, todos os itens de origem animal apresentaram os maiores valores do índice alimentar no sítio A, enquanto que no sítio B detritos e gramíneas foram mais abundantes. A composição dos itens ingeridos variou sazonalmente, sendo a maior diversidade registrada durante o período da primavera para ambos os sítios. Indivíduos pequenos preferiram itens de origem animal enquanto que os maiores consumiram principalmente itens de origem vegetal. De acordo com seu tamanho A. aff. fasciatus neste estudo pode ser considerada uma espécie com tendências à insetivoria quando imaturo, ou à herbivoria quando adulto. No entanto, seu hábito alimentar pode ser flexível de acordo com a disponibilidade de recursos, mostrando ampla variação tanto ontogenética quanto espacial e temporal.

Key words: Resource availability, Feeding flexibility, Omnivore, Niche shifts, Freshwater.

${ }^{1}$ Departamento de Biologia Celular,Universidade Federal do Paraná. Caixa Postal 19031, 81531-990 Curitiba, PR, Brazil. luciano_biol@yahoo.com.br; flaviasrios@ufpr.br; donatti@ufpr.br

${ }^{2}$ Grupo de pesquisas em Ictiofauna, Museu de História Natural Capão da Imbuia (MHNCI), 82810-080 Curitiba, PR, Brazil. vabilhoa@uol.com.br 


\section{Introduction}

The Atlantic Forest is one of the world's hotspots of biological diversity. It has been submitted to an intense process of destruction and fragmentation of its current ecosystems, due to disorganized urban expansion, industrial activities and agriculture (Myers et al., 2000). This process has affected the integrity of aquatic systems, mainly in small and medium-sized rivers, causing loss of important information about its biota (Buckup, 1996; Faria \& Marques, 1999). Knowledge of the feeding and trophic organization of the species can contribute to the understanding of the fish's autoecology in rivers and tropical streams, which in turn can provide data for preserving these fragile ecosystems.

The variation in the availability of feeding resources plays a central role in the alterations of feeding patterns in fish, both on a temporary and spatial scale (Prejs \& Prejs 1987; Winemiller \& Winemiller 2003). Furthermore, the alterations in feeding habits can also be conditioned to the ontogenetic development of morphological structures of species, such as dentition, intestinal tract, mouth size and improved locomotion, mainly during the transitional phase between juvenile and adult (Wootton, 1999; Hahn et al., 2000). However, this approach has not yet received suitable attention in ecological trophic studies.

The genus Astyanax Baird \& Girard, 1854 is diverse and widespread in freshwaters of South America, including almost one hundred described species (Lima et al., 2003). Several Astyanax species are abundant and distributed throughout Brazilian hydrographic basins, mostly in small streams, feeding mainly on algae and aquatic and terrestrial insects (Costa, 1987; Esteves, 1996; Casatti \& Castro, 1998). Astyanax species are also of great ecological importance, maintaining trophic relations in the communities, since it is fodder for some carnivorous species (Almeida et al., 1997; Loureiro-Crippa \& Hahn, 2006). Moreover, the genus is also important in the integrity of the riparian vegetation, where these fish are considered as potential seed scatterers (Vilella et al., 2002).

In the last few years, the name Astyanax fasciatus was atributed to several fishes collected in the rio Paraná basin (Shibatta et al., 2002; Castro et al., 2003; Artoni et al., 2006), following the diagnostic attributes proposed by Eigenmann (1921), such as the number of anal-fin rays (25 or more), the presence of an elongated humeral spot, a silvery lateral band turning black on the caudal peduncle and continuing as a black streak to the end of the middle fin rays, and one to three maxillary teeth. However, several authors refer to this species as a "species complex", based on chromosomal data (Justi, 1993; Artoni et al., 2006) and morphological analyses (Garutti \& Britski, 2000). In fact, Melo (2005) stated that the name $A$. fasciatus should be applied only to specimens from the São Francisco drainage, and specimens from rio Paraná drainage may represent a complex of similar species.

Considering the trophic potential and the ability of most of the species of Astyanax to colonize different habitats, this study was carried out with the objective of answering the following question: Can ontogenetic variation, seasonal regime and environmental heterogeneity (of an Atlantic Forest river in Southern Brazil) induce modifications in the diet composition of the species?

\section{Material and Methods}

Study area. This study was performed in the rio das Pedras, located in Guarapuava, in the central-eastern part of Paraná State, Southern Brazil. It is one of the rivers that form the rio Jordão, the main tributary of the middle rio Iguaçu. The rio Iguaçu is world famous, known for the Iguaçu waterfalls. The falls have contributed to the isolation of ichthyofauna associated with its superior level and proportionally to a high degree of fish endemism in the area of this study. This region is situated in the Mixed Ombrophylous Forest, which is a biome subdivision of the Atlantic Forest. The region's climate is considered subtropical with an average annual rainfall of 1600 to $1800 \mathrm{~mm}$ and the average annual temperature of 15 to $18^{\circ} \mathrm{C}$ (climatic period between 1976 and 2000, Fig. 1, Meteorological System of Paraná). Two sites with distinct environmental and hydrological characteristics were chosen for the sampling of $A$. aff. fasciatus specimens.

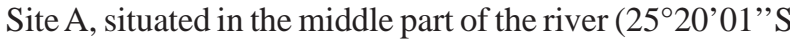
$51^{\circ} 21^{\prime} 27^{\prime \prime} \mathrm{W}$ ) has a channel width between 15 and $18 \mathrm{~m}$, with alternating by shallow riffles and large pools that do not exceed $2 \mathrm{~m}$ of depth. The riverbanks are partially covered by relatively preserved riparian vegetation, and its channel bed is covered predominantly by rocky substrate, e.g., cobbles (64-256 mm) and small boulders (257-512 mm) in the riffles and sand-gravel, clay and organic matter in the pool regions. In the pools the water-land interface of the littoral zone shows marginal vegetation composed predominately of the exotic grass Brachiaria sp. and submersed aquatic macrophytes. Site B is situated downstream ( $25^{\circ} 23^{\prime} 57^{\prime \prime} \mathrm{S} 51^{\circ} 26^{\prime} 10^{\prime \prime} \mathrm{W}$ ) and has slow water characteristics with a channel width between 25 and $27 \mathrm{~m}$ and depth of about $1.5 \mathrm{~m}$. The riparian vegetation is simple, predominated by generalist and pioneer species such

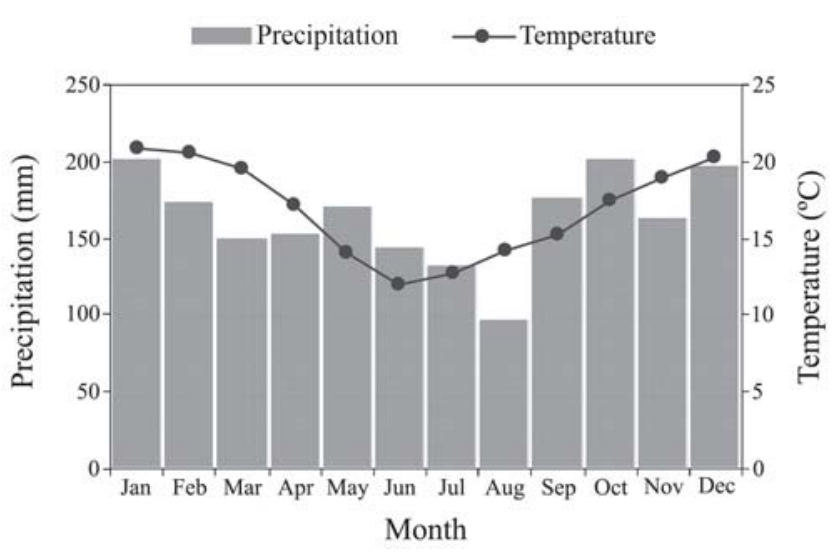

Fig. 1. Monthly average precipitation and temperature for the rio das Pedras region, Guarapuava, PR, Brazil. (Data refer to the period of January 1976 to December 2000). Source: SIMEPAR. 
as "bamboos" (Bambusoideae) and variety climbers. The channel bed is covered mainly by sand-clay substrate and deposited organic material. Vegetation at the water-land interface is practically absent as described for site A. During the study period, measures of turbidity, depth, water flow, $\mathrm{pH}$, water temperature, and dissolved oxygen were recorded.

Fish collection. The specimens were obtained through monthly samples carried out from March 2005 to February 2006. Fish gillnets ( $15 \times 1.5 \mathrm{~m}$ with $12,15,20$ and $25 \mathrm{~mm}$ mesh), traps (50 mm opening) and a dragnet with $3 \mathrm{~mm}$ mesh were used. After capture the individuals were fixed in $10 \%$ formalin and then transferred to $70 \%$ alcohol.

In the laboratory, they were identified, weighed, measured and dissected for stomach removal. Voucher $A$. aff. fasciatus collected in this study were deposited in the Ichthyological Collection of the Museu de História Natural Capão da Imbuia, Curitiba, Paraná, Brazil (MHNCI 11731).

Species identification. The species studied here was diagnosed from other sympatric Astyanax species by the following morphological characters: two vertically elongate dark humeral spots, second one faint; dorsal, anal and caudal fins red in life; outer row of teeth on premaxilla with four teeth; posteroventral edge of third infraorbital almost contacting preoperple; lateral line series with 36-40 perforated scales; first gill arch with 7-9 + 10-13 gill rakers (Sampaio, 1988).

Feeding study. The stomach contents of 290 specimens were identified under a microscope to the smallest possible taxonomic level. The diet of $A$. aff. fasciatus was analyzed accordingly to two combined methods. First, the frequency of occurrence was calculated, considering the number of samples (stomachs) that contain a certain item (i). It is expressed as the percent frequency of the total number of analyzed samples (Hynes, 1950). Second, the volumetric frequency (relative volume) was estimated taking into account the quantitative contribution of each item. It was determined by the number of checkered squares occupied by each item (i) on millimeter-ruled paper (points method), in relation to the total number of squares occupied by all of the items (Hyslop, 1980). The feeding index $\left(I_{\mathrm{F}}\right)$ proposed by Kawakami \& Vazzoler (1980) was calculated as $I_{\mathrm{F}}=F_{i} \cdot V_{i} / \Sigma\left(F_{i} \cdot V_{i}\right)$, where $i=$ feeding item, $F_{i}=$ frequency of occurrence and $V_{i}=$ volume, to analyze the effective importance of the presence and volume of each specific item. To aid in the graphic interpretation of results, the items that were ingested by $A$. aff. fasciatus were grouped into taxonomic or wider ecological categories.

Seasonal dietary analysis. The Morisita-Horn index (Krebs, 1998), applied to the $I_{\mathrm{F}}$ values, was used to analyze the feeding patterns between the two sites and among the four seasons. In order to determine the similarity patterns, the similarity food matrix was reduced through cluster analysis, using the Euclidean distance algorithm (Ward's methods) as a dissimilarity measure. The seasons were defined in the following manner; autumn (March, April, May of 2005), winter (June, July and August of 2005), spring (September, October and November of 2005), and summer (December of 2005, January and February of 2006).

Ontogenetic dietary analysis. For the ontogenetic study, three classes of standard lengths (SL) were considered as follows: standard length $1\left(\mathrm{SL}_{1}\right)$ with individuals up to $50 \mathrm{~mm}$; standard length $2\left(\mathrm{SL}_{2}\right)$ with individuals between $51 \mathrm{~mm}$ and $75 \mathrm{~mm}$; and standard length $3\left(\mathrm{SL}_{3}\right)$ with individuals over $76 \mathrm{~mm}$. The first class ( $\mathrm{SL}_{1}$ ) was established on the basis of the sexual maturity curve, previously determined for the species and therefore considered immature individuals. The other two classes were determined arbitrarily. The standard length of specimens ranged from $16 \mathrm{~mm}$ to $125 \mathrm{~mm}$. The feeding patterns among the three classes of individual size were identified by detrended correspondence analysis (DCA; Hill \& Gauch Jr., 1980), applied to the $I_{\mathrm{F}}$ values. The intestinal quotient $\left(I_{\mathrm{q}}\right)$ was calculated using 20 specimens of each class in order to identify the possible causes of alterations in the feeding behavior among the classes (Zavala-Camin, 1996). The intestinal quotient is the result of the division of the intestinal length (measured in centimeters) by standard length of the fish. The $I_{\mathrm{q}}$ of the different classes were tested using analysis of variance (ANOVA), assuming the prerequisites of normality and homogeneity of the variances, with the level of significance set at 5\% (Zar, 1996). This test was conducted using the software Statistica 7.1 (Stasoft, 2005).

\section{Results}

Abiotic condition. During the study period, the abiotic variables that showed the largest seasonal fluctuation were turbidity, depth and water flow, with the highest mean values recorded during the spring for both study areas. It characterized spring as a wet period. Water temperature was highest during the summer for both sites, whereas $\mathrm{pH}$ and dissolved oxygen varied little throughout the study (Table 1).

Spatial diet composition. At both sites, A. aff. fasciatus exhibited a broad feeding spectrum. The diet was based on

Table 1. Seasonal abiotic variables at two sites studied on the rio das Pedras (mean values).

\begin{tabular}{lcccc}
\hline & Autumn & Winter & Spring & Summer \\
\hline \multicolumn{1}{c}{ Site A } & & & & \\
Turbidity (ntu) & 12.6 & 9.9 & 16.5 & 15 \\
Depth (m) & 1.2 & 1.2 & 1.7 & 1.1 \\
Water flow $\left(\mathrm{m}^{3} \mathrm{~s}^{-1}\right)$ & 5.3 & 3.6 & 12.3 & 2.6 \\
pH & 7.2 & 7.3 & 6.9 & 7.1 \\
Water temperature $\left({ }^{\circ} \mathrm{C}\right)$ & 16.8 & 12.3 & 15.3 & 20.1 \\
Dissolved oxygen $\left(\mathrm{mgl}^{-1}\right)$ & 8.6 & 9 & 8.9 & 7.5 \\
$\quad$ Site B & & & & \\
Turbidity (ntu) & 12.4 & 9.6 & 21.1 & 12.3 \\
Depth (m) & 1.4 & 1.5 & 2,6 & 1.47 \\
Water flow (m $\left.{ }^{3} \mathrm{~s}^{-1}\right)$ & 10.2 & 11.5 & 30.2 & 8.3 \\
pH & 7.3 & 7.1 & 7 & 7.2 \\
Water temperature $\left({ }^{\circ} \mathrm{C}\right)$ & 16.5 & 14 & 17 & 22 \\
Dissolved oxygen $\left(\mathrm{mgl}^{-1}\right)$ & 8.4 & 9.1 & 8.6 & 7.1 \\
\hline
\end{tabular}


leaves and insect fragments, but also showed seeds, fruits, filamentous algae, and aquatic and terrestrial insects. There was a clear difference in the exploration of these resources between the two sites sampled. $I_{\mathrm{F}}$ values highlighted insect fragments as the main item for site $\mathrm{A}$ and leaf fragments for site $B$ (Table 2). In general, the consumption of items of animal origin was comparatively higher for the individuals of site A when compared to site $\mathrm{B}$. The consumption of resources of plant origin predominated at site B. Sediments and detritus were more frequently consumed at site B (Fig. 2).

Table 2. Diet composition of Astyanax aff. fasciatus expressed as the feeding index $\left(I_{\mathrm{F}}\right)$ at two sites on the rio das Pedras. (* Values $<0.1$; - item not recorded).

\begin{tabular}{lcc}
\hline & Site A & Site B \\
\hline Leaf fragments & 19.8 & 65.8 \\
Insect fragments & 55.8 & 19.4 \\
Seeds and fruits & 4.5 & 4.2 \\
Grass & 0.5 & 3.8 \\
Filamentous algae & 1.1 & 0.4 \\
Formicidae & 10.3 & 2.5 \\
Lepidoptera & 0.7 & 0.2 \\
Adult Diptera & 0.9 & 0.3 \\
Immature Diptera & 0.6 & 0.1 \\
Aranae & 0.1 & $*$ \\
Coleoptera & 0.8 & 0.1 \\
Odonata & 0.1 & $*$ \\
Ephemeroptera & 2.6 & 0.7 \\
Trichoptera & 0.3 & $*$ \\
Hemiptera & 0.1 & $*$ \\
Nematoda & $*$ & - \\
Plecoptera & 0.3 & $*$ \\
Detritus & 1.3 & 2.2 \\
Sediments & $*$ & 0.2 \\
\hline
\end{tabular}
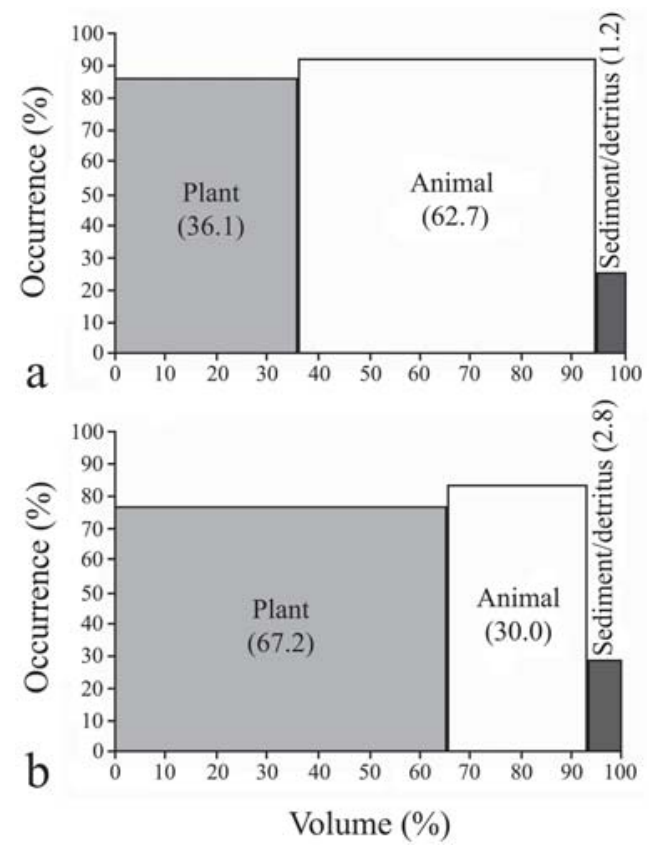

Fig. 2. Diet composition of Astyanax aff. fasciatus at sites A (a) and $\mathrm{B}$ (b) on the rio das Pedras, according to the origin of the ingested items (value between parentheses corresponds to the feeding index of each category).
Seasonal diet composition. The great diversity of items recorded in the stomach content of $A$. aff. fasciatus occurred during the spring at both sites studied. At site A, the most important items during the spring and autumn were insect. fragments. Leaf fragments predominated during the summer, while there was a marked contribution of insects (Ephemeroptera nymphs) during the winter (Table 3). At site $\mathrm{B}$, leaf fragments were the most important item during all the seasons (Table 3).

Plants and invertebrates were present in high amounts in almost all seasons and at both sites (Fig. 3 ). The plant category was not recorded only during the winter at site A. The terrestrial invertebrate category was of high importance during the spring and summer at site $\mathrm{A}$, and during the summer at site B. The aquatic invertebrate category was substantially more frequent during the winter at site $\mathrm{A}$. The terrestrial vegetation category showed high importance during the autumn and summer for both sites. The aquatic vegetation category showed low frequency during the spring and the autumn at site B. Detritus and sediments were also absent only during the winter at site A, but this category was uncommon during the whole study period (Fig. 3).

Comparing the diet of $A$. aff. fasciatus between the two sites and among the different seasons using cluster analysis it was possible to establish three distinct groups according to feeding similarity. The first group was characterized by all of the seasons at site B and the summer at site A. The second group was composed of autumn and spring seasons at site A. And the third group was formed only by winter at site A, which showed high dissimilarity with the other groups (Fig. 4).

Table 3. Diet composition of Astyanax aff. fasciatus expressed as the feeding index $\left(I_{\mathrm{F}}\right)$ at sites $\mathrm{A}$ and $\mathrm{B}$ on the rio das Pedras, according to season. (* Values $<0.1$; - item not recorded).

\begin{tabular}{|c|c|c|c|c|c|c|c|c|}
\hline \multirow[b]{2}{*}{ Food items } & \multicolumn{2}{|c|}{ Autumn } & \multicolumn{2}{|c|}{ Winter } & \multicolumn{2}{|c|}{ Spring } & \multicolumn{2}{|c|}{ Summer } \\
\hline & $\begin{array}{c}\text { Site } \\
\text { A }\end{array}$ & $\begin{array}{c}\text { Site } \\
\text { B }\end{array}$ & $\begin{array}{c}\text { Site } \\
\text { A }\end{array}$ & $\begin{array}{c}\text { Site } \\
\text { B } \\
\end{array}$ & $\begin{array}{c}\text { Site } \\
\text { A }\end{array}$ & $\begin{array}{c}\text { Site } \\
\text { B }\end{array}$ & $\begin{array}{c}\text { Site } \\
\text { A }\end{array}$ & $\begin{array}{c}\text { Site } \\
\text { B }\end{array}$ \\
\hline Leaf fragments & 26 & 43.8 & - & 83.7 & 6.7 & 71.3 & 47.6 & 47.5 \\
\hline Insect fragments & 51 & 30.4 & 24.1 & 8.8 & 70.3 & 13.1 & 12.6 & 21.5 \\
\hline Seeds and fruits & 12.8 & 14.2 & - & 0.7 & 0.2 & 0.5 & 10.5 & 8.5 \\
\hline Grass & 0.2 & 2.1 & - & 2.5 & 1 & 8.4 & $*$ & - \\
\hline Filamentous algae & 1.6 & 1.8 & - & $*$ & - & - & 7.9 & 0.3 \\
\hline Formicidae & 4 & 0.9 & 0.1 & 1.6 & 13.2 & 3.9 & 11 & 2.2 \\
\hline Lepidoptera & 0.3 & 0.2 & - & 0.1 & 1.2 & $*$ & 0.3 & 0.6 \\
\hline Adult Diptera & - & - & - & 0.1 & 0.8 & 0.4 & 54 & 7.7 \\
\hline Immature Diptera & 0.2 & 0.3 & 0.1 & - & 1.1 & $*$ & 0.2 & 0.2 \\
\hline Aranae & 0.2 & - & 0.3 & - & 0.1 & 0.1 & - & - \\
\hline Coleoptera & 0.1 & - & - & - & 0.9 & 0.1 & 1.9 & 5.2 \\
\hline Odonata & $*$ & $*$ & - & - & 0.3 & - & $*$ & - \\
\hline Ephemeroptera & 0.8 & 0.6 & 75 & 0.9 & 1.6 & 0.4 & 1.9 & 0.9 \\
\hline Trichoptera & $*$ & $*$ & - & - & 0.7 & 0.1 & 0.3 & - \\
\hline Hemiptera & $*$ & $*$ & - & - & 0.3 & $*$ & - & - \\
\hline Nematoda & - & - & 0.1 & - & 0.1 & - & - & - \\
\hline Plecoptera & - & - & - & - & 1.1 & 0.1 & $*$ & - \\
\hline Detritus & 2.5 & 4.9 & - & 1.6 & 0.9 & 1.4 & 0.3 & 0.1 \\
\hline Sediments & $*$ & 0.2 & - & - & $*$ & - & - & 5.3 \\
\hline $\mathrm{N}^{\mathrm{o}}$ of individuals & 47 & 54 & 12 & 18 & 60 & 44 & 36 & 20 \\
\hline
\end{tabular}



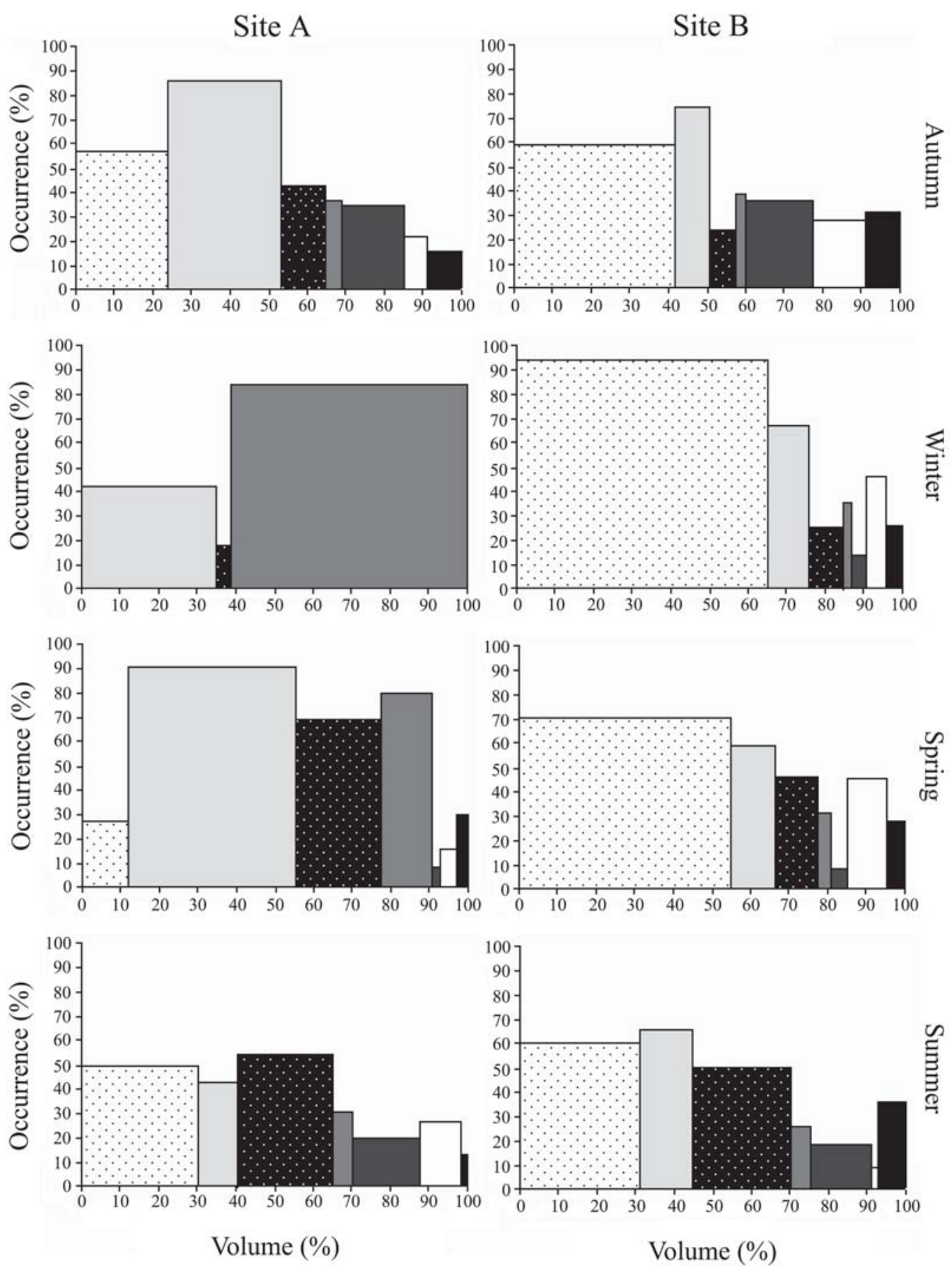

Fig. 3. Diet composition of Astyanax aff. fasciatus at two sites on the rio das Pedras, according to season. Categories: plants, $\square$ invertebrates, $\because$ terrestrial invertebrates, $\square$ aquatic invertebrates, $\square$ terrestrial vegetation, $\square$ aquatic vegetation and $\square$ sediments and detritus.

Ontogenetic diet composition. Astyanax aff. fasciatus showed a tendency to shift its feeding niche during growth. The consumption of items of animal origin was higher in smaller individuals, but it decreased in the larger ones, which consumed more plant items. This shift was more noticeable at site B (Fig. 5). At both sites, the most important item in the diet of the $\mathrm{SL}_{1}$ individuals was insect fragments. On the other hand, the larger individuals $\left(\mathrm{SL}_{3}\right)$ consumed mainly leaf fragments (Table 4).

Detrended correspondence analysis (DCA) demonstrated a distinct feeding segregation between the individuals of the different size classes (Fig. 6). The DCA axis 1 explained $54.3 \%$ of the variability and divided the size classes into three groups. The first group (scores positively related) was represented by $\mathrm{SL}_{1}$ individuals and the second group (intermediate scores) by $\mathrm{SL}_{2}$ individuals, while the 


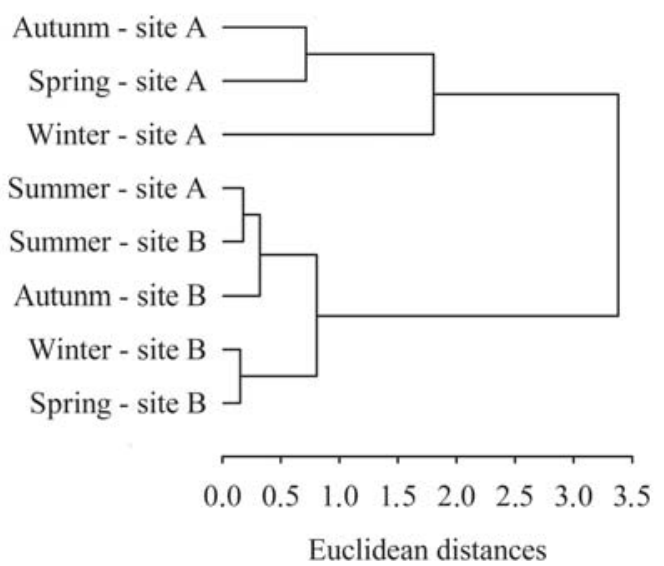

Fig. 4. Representation of the similarity patterns (Euclidean distances) in the seasonal and spatial diet composition of Astyanax aff. fasciatus at two sites on the rio das Pedras, Guarapuava, PR, Brazil. third group (negatively related scores) comprised $\mathrm{SL}_{3}$ individuals. During growth, $A$. aff. fasciatus showed morphological alteration in the intestinal length/standard length ratio. The intestinal quotient $\left(I_{\mathrm{q}}\right)$ was significantly larger in the $\mathrm{SL}_{2}$ and $\mathrm{SL}_{3}$ size classes $\left(\mathrm{F}_{2,57}=28.1 ; \mathrm{P}<0.05\right.$; $r=0.50$; Fig. 7).

\section{Discussion}

Several papers have reported the existence of a marked feeding flexibility in species of Astyanax (Arcifa et al., 1991; Esteves, 1996; Hahn et al., 1997; Vilella et al., 2002). Usually, these species use diverse items varying from algae and higher plants to insects and other arthropods. The present results corroborate this trend, indicating that $A$. aff. fasciatus exhibited an omnivorous diet including 20 items, of either animal or plant origin. However, these results do not allow a trophic categorization, because of the ontogenetic variation,
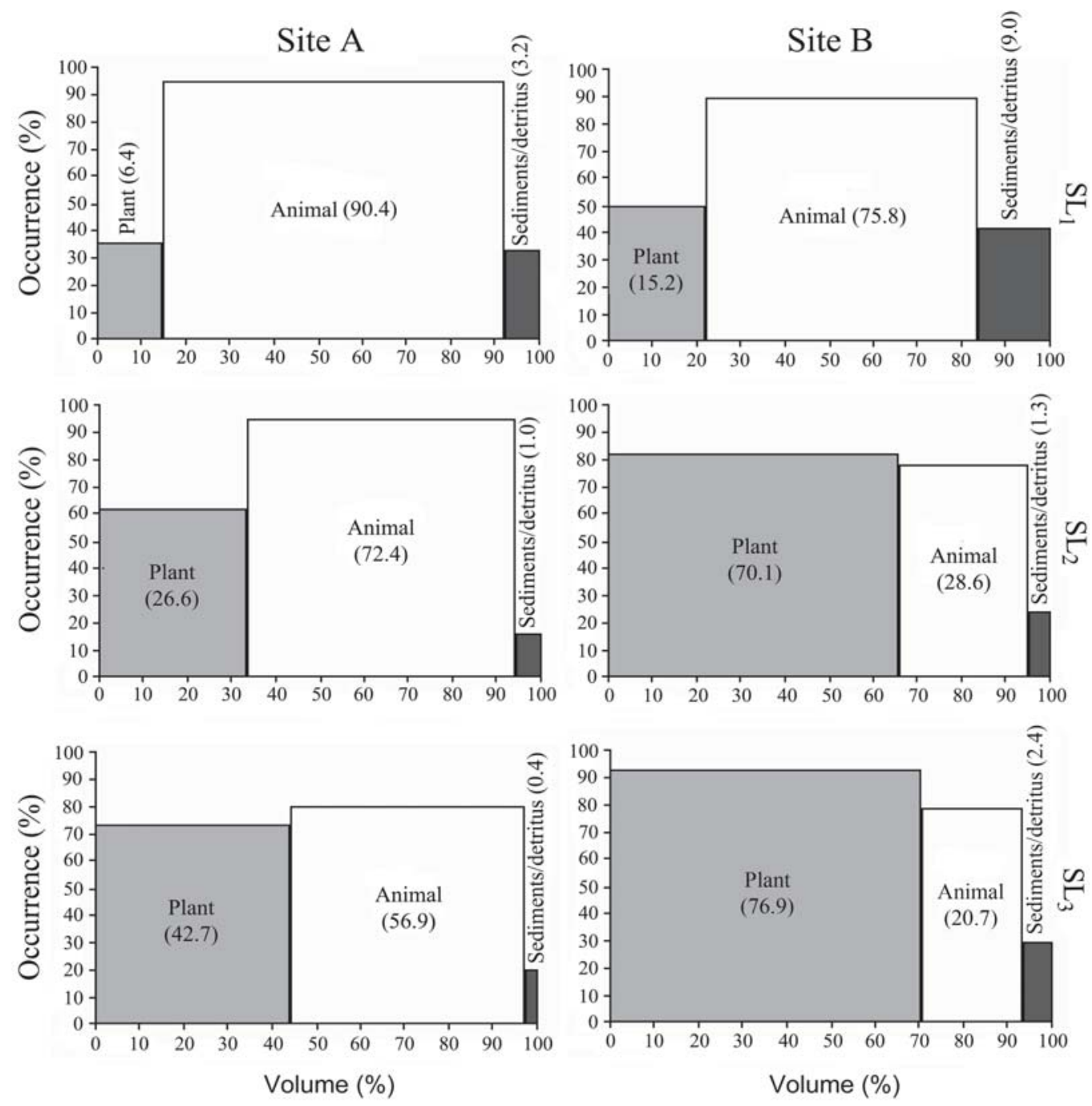

Fig. 5. Diet composition of Astyanax aff. fasciatus among the three established standard length classes, and according to the

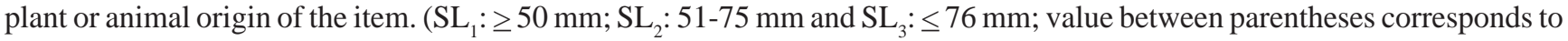
the feeding index of each category). 
Table 4. Diet composition of Astyanax aff. fasciatus expressed as the feeding index $\left(I_{\mathrm{F}}\right)$ at two sites on the rio das Pedras, according to individual size. ( $\mathrm{SL}_{1}: \geq 50 \mathrm{~mm} ; \mathrm{SL}_{2}: 51-75 \mathrm{~mm}$ and $\mathrm{SL}_{3}: \leq 76 \mathrm{~mm}$; * Values $<0.1$ and - items not recorded).

\begin{tabular}{lccccccc}
\hline \multirow{2}{*}{ Food items } & \multicolumn{3}{c}{$\mathrm{Site} \mathrm{A}$} & & \multicolumn{3}{c}{ Site B } \\
\cline { 2 - 4 } \cline { 6 - 8 } & $\mathrm{SL}_{1}$ & $\mathrm{SL}_{2}$ & $\mathrm{SL}_{3}$ & & $\mathrm{SL}_{1}$ & $\mathrm{SL}_{2}$ & $\mathrm{SL}_{3}$ \\
\hline Leaf fragments & 3.7 & 13.5 & 38.1 & & 4.0 & 74.3 & 74.5 \\
Insect fragments & 72.2 & 61.2 & 31.7 & & 74.9 & 18.7 & 9.5 \\
Seeds and fruits & 0.2 & 5.2 & 6.4 & & 7.1 & 0.7 & 4.1 \\
Grass & 0.2 & 0.1 & 1.5 & & $*$ & 2.1 & 6.1 \\
Filamentous algae & 1.8 & 2.7 & - & & 0.5 & 0.1 & 0.4 \\
Formicidae & 1.4 & 10.2 & 16.9 & & 2.3 & 1.6 & 1.8 \\
Lepidoptera & 0.4 & 0.5 & 1.2 & & - & - & 0.4 \\
Adult Diptera & 1.3 & 0.8 & 0.9 & & 0.4 & 0.1 & 0.5 \\
Immature Diptera & 3.9 & 0.3 & 0.1 & & 0.9 & 0.2 & - \\
Aranae & $*$ & 0.2 & $*$ & & - & - & 0.1 \\
Coleoptera & 0.1 & 1.6 & 0.6 & & 1.4 & 0.1 & $*$ \\
Odonata & 0.1 & 0.1 & 0.2 & & 0.1 & - & - \\
Ephemeroptera & 11.4 & 1.4 & 0.7 & & 1.0 & 1.5 & 0.3 \\
Trichoptera & 0.1 & 0.2 & 0.5 & & - & $*$ & 0.1 \\
Hemiptera & $*$ & $*$ & 0.3 & & 0.2 & - & $*$ \\
Nematoda & 0.1 & - & 0.1 & & - & - & - \\
Plecoptera & 0.3 & 0.5 & 0.2 & & - & 0.1 & - \\
Detritus & 2.7 & 1.5 & 0.5 & & 6.2 & 0.3 & 2.2 \\
Sediments & 0.3 & 0.1 & - & & 1.0 & 0.4 & 0.1 \\
\hline$N^{\circ}$ of individuals & 54 & 59 & 42 & & 38 & 38 & 60 \\
\hline
\end{tabular}

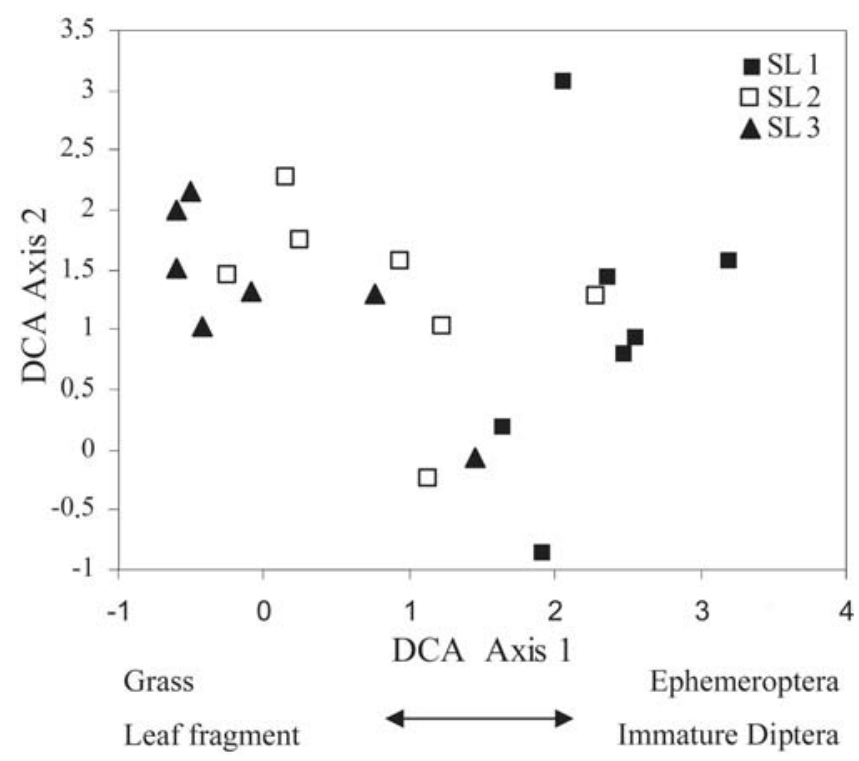

Fig. 6. Ordination of individuals of Astyanax aff. fasciatus of different sizes according to the higher feeding preference.

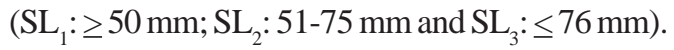

as well as spatial and seasonal modifications in the composition of its diet. This was observed in other characin species (Luz \& Okada, 1999; Mazzoni \& Rezende, 2003).

According to Winemiller \& Winemiller (2003), fish diets can be regulated by spatial and seasonal habit modifications. This takes into account that distinct areas and periods show differences in abiotic conditions and food availability for fishes. Spatial differences in the $\operatorname{diet}$ of $A$. aff. fasciatus were

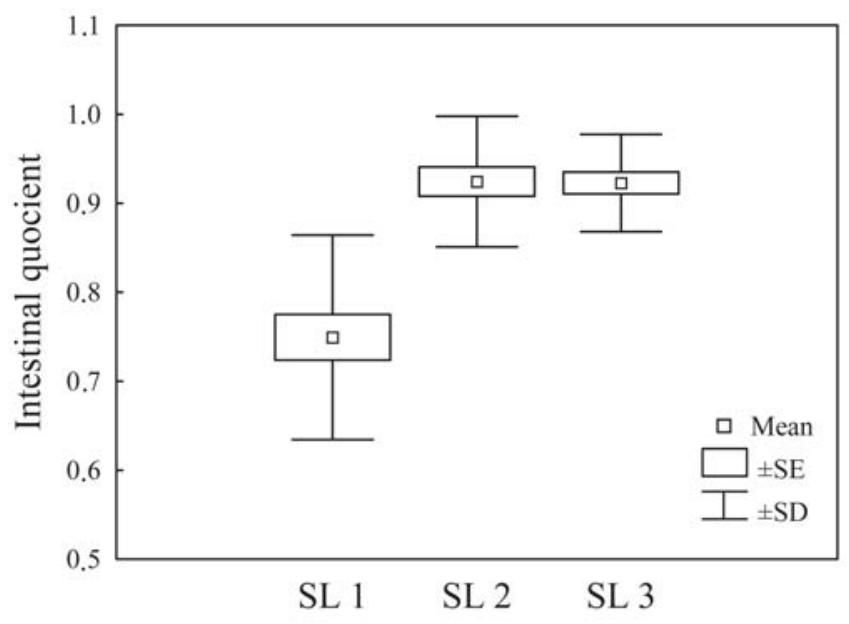

Fig. 7. Mean \pm S.D. Intestinal quotient $\left(I_{q}\right)$ of the three established standard length classes for Astyanax aff. fasciatus at two sites on the rio das Pedras. $\left(\mathrm{SL}_{1}: \leq 50 \mathrm{~mm} ; \mathrm{SL}_{2}: 51-75\right.$ $\mathrm{mm}$ and $\left.\mathrm{SL}_{3}: \geq 76 \mathrm{~mm}\right)$.

high. Animal-derived items were essential for the specimens captured at site A, while leaf fragments, grass and detritus exhibited a greater importance at site B. This feeding flexibility may be attributed to different factors, including the degree of riparian vegetation disturbance and the physical characteristics of the river at the sites studied.

Riparian areas exhibit important hydrological and ecological functions for the integrity of the aquatic biota, constituting one of the main feeding resources for many fishes (Esteves \& Aranha, 1999). At site B, the riparian covering is simple with predominately shrubby vegetation such as, bamboos and climbers. As a consequenc of this low structural complexity in vegetation, it is possible that the availability of allochthonous resources, such as insects and other arthropods had been reduced (Uieda \& Kikuchi, 1995), which explains the predominantly herbivorous diet at this site.

The observed difference in feeding spectrum of $A$. aff. fasciatus can also be related to the difference in availability of macroinvertebrates between the two sites. The abundance and distribution patterns of aquatic insects are determined mainly by the type and quantity of substrate. According to Blanco-Belmonte et al. (1998), the presence of vegetation in an aquatic ecosystem considerably increases the richness and abundance of these organisms. Unlike site B, where the river's stretch is characterized by riverbanks with little vegetation at the warter-land interface, the river's stretch corresponding to site A shows a higher amount of vegetation which is mainly composed of grass and submersed aquatic macrophytes in the pool regions. In view of these characteristics, it is possible that the development of macroinvertebrates is favored in this area, making them available as a food source for the ichthyofauna.

The seasonal diet analysis of $A$. aff. fasciatus, revealed 
differences in the proportion as well as in the variety of ingested items. According to Wootton (1999), the seasonal changes in the diet of fish can be due to expansion and contraction of available foraging areas. In tropical regions, the variation in patterns of the hydrological season leads to flooded areas adjacent to the rivers. The vegetation flooded during this process could supply a great quantity of organic matter for ichthyofauna feeding. Astyanax aff. fasciatus seems to be adapted to these dynamics, because its feeding niche range was higher during the spring which showed the highest hydrological levels.

Besides the elevation in the water level, other possible natural events could influence the feeding habits of $A$. aff. fasciatus. The consumption of terrestrial invertebrates was greater during the spring and summer at both studied sites. This was probably associated with the ant reproductive period, because winged individuals (flying ants) were found in the stomach content of $A$. aff. fasciatus only during this period. In their reproductive flights, it is possible that many ants fall into the water where are, ingested by fishes.

On the contrary, the consumption of terrestrial vegetation (seed and fruits), more frequent during the summer and autumn corresponds to the fruiting of various arboreal species in region. In the present study, intact seeds of Schinus sp. (pepper tree) were present in the stomach contents and intestinal tract of $A$. aff. fasciatus. The presence of these seeds suggests a potential role in seed dispersal, as proposed for other species of characins (Vilella et al., 2002).

Aquatic invertebrates, especially Ephemeroptera, were substantially consumed during the winter at site A. During this time, all fish collections contained just small individuals $\left(\mathrm{SL}_{1}\right)$. This was probably related to the low mean temperature, which can decrease the basal metabolism in fishes and consequently their capture. Therefore, this does not represent the whole range of items that the species (e.g. $\mathrm{SL}_{2}$ and $\mathrm{SL}_{3}$ individuals) could use during that period.

Sediments and detritus were of little importance during nearly all the study period. These items can constitute the base diet for some species of Neotropical fishes (Bowen, 1983). However, its contribution has been minor for the characins in most of the works carried out (Esteves \& Galletti Jr., 1995; Esteves, 1996). Bowen (1983) emphasized that the ingestion of these items by species could occur accidentally during foraging, or when the other preferential resources are scarce, but that this is not related to detrivory adaptation.

There is a tendency among the individuals of $A$. aff. fasciatus to reduce the consumption of animal origin items, substituting it with plant-derived items during growth. These results are probably associated with morphological changes in the digestive tract during its development. As an example, their intestinal quotient $\left(I_{q}\right)$ was significantly less for the smallest $\left(\mathrm{SL}_{1}\right)$ individuals. This correlates with the results obtained by Sabino \& Castro (1990) for Deuterodon iguape, indicating that the low values of $I_{\mathrm{q}}$ in immature individuals are related predominantly to an insect diet. Conversely, the individuals of the $\mathrm{SL}_{2}$ and $\mathrm{SL}_{3}$ size classes showed an intestinal length significantly longer indicating the possibility of the intake of items of larger size and more difficult to digest, such as plant fragments and seeds with rigid cell walls.

Distinct diets among the different development stages of a species can derive from differences in energy demands or from the morphological limitations of each stage. For instance, the ingestion of large items by fingerlings can be limited by the mouth opening (Wootton, 1999; Abelha et al., 2001; Vitule et al., 2008). This limitation can be emphasized looking at $A$. aff. fasciatus where items such as leaf fragments, seeds, fruits and Formicidae tended to be of low importance in $\mathrm{SL}_{1}$ in relation to items such as immature Diptera and Ephemeroptera which were more important and considered small items.

It is important to emphasize that most of the immature A. aff. fasciatus individuals were captured using drag nets next to the riverbank vegetation, where as indicated by Blanco-Belmonte et al. (1998) the aquatic insects are more abundant. This suggests a spatial segregation among individuals of different sizes, and therefore, it is possible that small individuals use extensively the resource available on the riverbank, reflected as being the most important food items.

\section{Acknowledgements}

We thank CAPES for providing Luciano L. Wolff with a MSc. fellowship. The Paraná Meterological System (SIMEPAR) for the supply of climatic data and Paraná Sanitation Company (SANEPAR - Unidade de Guarapuava, PR) for carrying out chemical studies. We are also grateful to Marcos Barbosa and Gelson Feslki for assistance with field sampling and to Norma S. Hahn for suggestions.

\section{Literature Cited}

Abelha, M. C. F., A. A. Agostinho \& E. Goulart. 2001. Plasticidade trófica em peixes de água doce. Acta Scientiarum, 23: 425-434.

Almeida, V. L. L., N. S. Hahn \& A. E. A. M. Vazzoler. 1997. Feeding patterns in five predatory fishes of the high Paraná River floodplain (PR, Brazil). Ecology of Freshwater Fish, 6: 123-133.

Arcifa, M. S., T. G. Northcote \& O. Froehlich. 1991. Interactive ecology of two cohabiting characin (Astyanax fasciatus and Astyanax bimaculatus) in an eutrophic Brazilian reservoir. Journal of Tropical Ecology, 7: 257-268.

Artoni, R. F., O. A. Shibatta, M. C. Gross, C. H. Schneider, M. C. Almeida, M. R. Vicari \& L. A. C. Bertollo. 2006. Astyanax aff. fasciatus Cuvier, 1819 (Teleostei; Characidae): evidences of a species complex in the upper rio Tibagi basin (Paraná, Brazil). Neotropical Ichthyology, 4: 197-202.

Blanco-Belmonte, L., J. J. Neiff \& A. Poi de Neiff. 1998. Invertebrate fauna associated with floating macrophytes in the floodplain lakes of the Orinoco (Venezuela) and Paraná (Argentina). Verhein International Verein Limnologie, 26: 20302034. 
Bowen, S. H. 1983. Detrivory in neotropical fish communities. Environmental Biology of Fishes, 9: 137-144.

Buckup, P. 1996. Biodiversidade de peixes da Mata Atlântica. In: Resumos do "Workshop” padrões de biodiversidade da Mata Atlântica do sudeste e sul do Brasil. Available from: http// www.bdt.org.br/workshop/mata.atlantica. 26 March 2007.

Casatti L. \& R. M. C. Castro. 1998. A fish community of the São Francisco river headwaters riffles, southeastern Brazil. Ichthyological Explorations of Freshwaters, 9: 229-242.

Castro, R. M. C., L. Casatti, H. F. Santos, K. M. Ferreira, A. C. Ribeiro, R. C. Benine, G. Z. P. Dardis, A. L. A. Melo, R. Stopiglia, T. X. Abreu, F. A. Bockmann, M. Carvalho, F. Z. Gibran \& F. C. T. Lima. 2003. Estrutura e composição da ictiofauna de riachos do rio Paranapanema, sudeste e sul do Brasil. Biota Neotropica, 3: 1-31.

Costa, W. J. E. M. 1987. Feeding habits of a fish community in a tropical coastal stream, rio Mato Grosso, Brazil. Studies on Neotropical Fauna Environment, 22: 145-153.

Eigenmann, C. H. 1921. The American Characidae. Memoirs of the Museum of Comparative Zoology, 23(3): 209-310.

Esteves, K. E. 1996. Feeding ecology of three Astyanax species (Characidae, Tetragonopterinae) from floodplain Lake of MogiGuaçú River, Paraná River basin, Brazil. Environmental Biology of Fishes, 46: 83-101.

Esteves, K. E. \& J. M. R. Aranha. 1999. Ecologia trófica de peixes de riachos. Pp.157-182. In: Caramaschi, E. P., R. Mazzoni \& P. R. Peres-Neto (Eds.). Ecologia de peixes de riachos. Oecologia Brasiliensis, vol 6. Rio de Janeiro, Programa de Pós-Graduação em Ecologia, Instituto de biologia UFRJ, Universidade Federal do Rio de Janeiro, 182p.

Esteves, K. E. \& P. M. Galletti Jr. 1995. Food partitioning among some characids of a small Brazilian floodplain lake from the Paraná River basin. Environmental Biology of Fishes, 42: 375389.

Faria, A. P. \& J. S. Marques. 1999. O desaparecimento de pequenos rios brasileiros. Ciência Hoje, 25: 57-61.

Garutti, V. \& H. A. Britski. 2000. Descrição de uma espécie nova de Astyanax (Teleostei: Characidae) da bacia do Alto Rio Paraná e considerações sobre as demais espécies do gênero na bacia. Comunicações do Museu de Ciências e Tecnologia da PUCRS, Série Zoologia, 13: 65-88.

Hahn, N. S., R. Fugi, V. L. L. Almeida, M. R. Russo \& V. E. Loureiro. 1997. Dieta alimentar de peixes do reservatório de Segredo. Pp. 141-162. In: Agostinho, A. A. \& L. C. Gomes (Eds.). Reservatório de Segredo: bases ecológicas para manejo. Maringá, EDUEM, 387p.

Hahn, N. S., C. S. Pavanelli \& E. K. Okada. 2000. Dental development and ontogenetic diet shifts of Roeboides paranensis Pignalberi (Osteichthyes, Characinae) in pools of the upper Rio Paraná floodplain (state of Paraná, Brazil). Revista Brasileira de Biologia, 60: 93-99.

Hill, M. O. \& H. G. Gauch Jr. 1980. Detrended correspondence analysis: an improved ordination technique. Vegetation, 42: 4758.

Hynes, H. B. N. 1950. The food of fresh-water sticklebacks (Gasterosteus aculeatus and Pygosteus pungitius), with a review of methods used in studies of the food of fishes. Journal of Animal Ecology, 19: 36-58.

Hyslop, E. J. 1980. Stomach contents analysis: a review of methods and their application. Journal of Fish Biology, 17: 411-429.

Justi, A. J. 1993. Caracterização cariotípica de populações de Astyanax fasciatus (Cuvier, 1819) Pisces, Characidae, em três bacias hidrográficas. Unplublished Master’s Thesis. Universidade Federal de São Carlos, São Carlos, 83p.

Kawakami, E. \& G. Vazzoler. 1980. Método gráfico e estimativa do índice alimentar aplicado no estudo da alimentação de peixes. Boletim do Instituto Oceanográfico, 29: 205-207.

Krebs, C. J. 1998. Ecological Methodology. Menlopark Addison Wesley, Longman, 620p.

Lima, F. C. T., L. R. Malabarba, P. A. Buckup, J. F. P. Silva, R. P. Vari, A. Harold, R. Benine, O. T. Oyakawa, C. S. Pavanelli, N. A. Menezes, C. A. S. Lucena, M. C. S. L. Malabarba, Z. M. S. Lucena, R. E. Reis, F. Langeani, L. Cassati, V. A. Bertaco, C. Moreira \& P. H. F. Lucinda. 2003. Genera Incertae Sedis in Characidae. Pp. 106-169. In: Reis, R. E., S. O. Kullander \& C. Ferraris (Eds.). Check List of the Freshwater Fishes of South and Central America. Porto Alegre, Edipucrs, 729p.

Loureiro-Crippa, V. E. \& N. S. Hahn. 2006. Use of food resources by the fish fauna of a small reservoir (rio Jordão, Brazil) before and shortly after its filling. Neotropical Ichthyology, 4: 357362.

Luz, K. D. G. \& E. K. Okada. 1999. Diet and dietary overlap of three sympatric fish species in lakes of the upper Paraná River floodplain. Brazilian Achieves of Biology and Technology, 42: 441-447.

Mazzoni, R. \& C. F. Rezende. 2003. Seasonal diet shift in a Tetragonopterinae (Osteichthyes, Characidae) from the Ubatiba River, RJ, Brazil. Brazilian Journal of Biology, 63: 69-74.

Melo, F. A. G. 2005. Revisão taxonômica do complexo de espécies Astyanax fasciatus (Cuvier, 1819) (Teleostei: Characiformes: Characidae). Unpublished Ph.D. Dissertation. Museu Nacional, UFRJ, 269p.

Myers, N., R. A. Mittermeier, C. G. Mittermeier, G. A. Fonseca \& J. Kent. 2000. Biodiversity hotspots for conservation priorities. Nature, 403: 853-858.

Prejs, A. \& K. Prejs. 1987. Feeding of tropical freshwater fishes: seasonality in resource availability and resource use. Oecologia, 71: 397-404.

Sabino, J. \& R. C. Castro. 1990. Alimentação, período de atividade e distribuição espacial dos peixes de um riacho de floresta atlântica (sudeste do Brasil). Revista Brasileira de Biologia, 50: 23-36.

Sampaio, F. A. A. 1988. Estudos taxonômicos preliminares dos Characiformes (Teleostei, Ostariophysi) da bacia do rio Iguaçu, com comentários sobre o endemismo dessa fauna. Unpublished Master's Thesis. Universidade Federal de São Carlos, São Carlos, 175p.

Shibatta, O. A., M. L. Orsi, S. T. Bennemann \& A. T. Silva-Souza. 2002. Diversidade e distribuição de peixes na bacia do rio Tibagi. Pp. 403-423. In: Medri, M. E., E. Bianchini, O. A. Shibatta \& J. A. Pimenta (Eds.). A bacia do rio Tibagi. Londrina, UEL, 595p.

Statsoft, Inc. 2005. Statistica (data analysis software system), version 7.1, Tulsa, OK. www.statsoft.com

Uieda, V. S. \& R. M. Kikushi. 1995. Entrada de material alóctone (detritos vegetais e invertebrados terrestres) num pequeno curso de água corrente (Cuestra de Botucatu, São Paulo). Acta Limnológica Brasiliensia, 3: 105-114.

Vilella, F. S., F. G. Becker \& S. M. Hartz. 2002. Diet of Astyanax species (Teleostei, Characidae) in an Atlantic forest river in southern Brazil. Brazilian Achieves of Biology and Technology, 45: 223-232.

Vitule, J. R. S., M. R. Braga \& J. M. R. Aranha. 2008. Ontogenetic, 
spatial and temporal variations in the feeding ecology of Deuterodon langei Travassos, 1957 (Teleostei: Characidae) in a Neotropical stream from the Atlantic rainforest, southern Brazil. Neotropical Ichthyology, 6 (2): 211-222.

Winemiller, K. O. \& L. C. Kelso-Winemiller. 2003. Food habits of tilapiine cichlids of the Upper Zambezi River and floodplains during the descending phase of the hydrological cycle. Journal of Fish Biology, 63: 120-128

Wootton, R. J. 1999. Ecology of teleostei fish. The Netherlands, Kluwer Academic Publishers, 386p.

Zar, J. H. 1996. Biostatistical analyses. New Jersey, Prentice Hall, 662p.

Zavala-Camin, L. A. 1996. Introdução aos estudos sobre alimentação natural em peixes. Maringá, EDUEM, 129p.

Accepted March 2009

Published June 17, 2009 